\title{
BUCKLING ANALYSIS OF TELESCOPIC BOOM: THEORETICAL AND NUMERICAL VERIFICATION OF SLIDING PADS
}

\author{
Ana Pavlovic, Cristiano Fragassa, Giangiacomo Minak
}

Original scientific paper

With the aim at improving the highest performances, materials in mechanical structures are constantly pushed closer and closer to their critical limits. Consider, for example, how the progressive reduction in thickness may lead to unforeseen effects in the instability of metal sheets, until the rapid collapse of the whole structure. This risk is specially known by designers of telescopic booms, used for moving aerial platforms. In this paper, by a numerical approach and ANSYS code, structural resistance and stability of a telescopic boom were verified. After a preliminary theoretical analysis, different loads and boundary configurations were considered in accordance with the most common conditions of real utilisation. As general result, it was confirmed that stresses were under the elastic limit of materials, except in a very limited number of contact zones, where specific connecting solutions have to be installed to prevent failures. Furthermore, linear buckling techniques showed that critical loads and corresponding buckling modes were higher than the most extreme working conditions; thus, structural stability was also confirmed. Finally, the large adoption of FEM simulations permitted to reduce the experiments, offering a fast methodology for improvements in design.

Keywords: aerial platform; FEM analysis; instability; telescopic boom; theoretical analysis

Analiza izvijanja teleskopske dizalice: teorijska i numerička procjena kliznih oslonaca

Izvorni znanstveni članak

U cilju poboljšanja najviših performansi, materijali u strojarskim konstrukcijama su često vođeni ka sve bližim i bližim kritičnim granicama. Razmotrimo, na primjer, kako progresivno smanjenje debljine može dovesti do nepredviđenih efekata u stabilnosti lima, sve do brzog loma cjelokupne konstrukcije. Ovaj rizik je posebice poznat konstruktorima teleskopskih dizalica, koje se koriste za pokretanje radnih platformi. U ovom radu, numeričkim pristupom i ANSYS kodom, čvrstoća i stabilnost teleskopske dizalice su verificirani. Nakon preliminarne teorijske analize, različite konfiguracije opterećenja i graničnih uvjeta su razmatrane u skladu s uvjetima realne uporabe. Kao opći rezultat, potvrđeno je da su naprezanja bila u okviru elastičnih granica materijala, osim u ograničenom broju kontaktnih površina, gdje su korišteni posebni kontaktni elementi za sprječavanje loma. Osim toga, linearne tehnike izvijanja su pokazale da su kritična opterećenja i odgovarajući moduli izvijanja bili veći od najtežih uvjeta rada; stabilnost je potvrđena. Konačno, FEM simulacije dopuštaju smanjenje brojnih eksperimenata, nudeći time brze metode za poboljšanje konstrukcija.

Ključne riječi: analiza FEM; izvijanje; teleskopska dizalica; teorijska analiza; zračna platforma

\section{Introduction}

Platforms with telescopic boom are machines used to work in particularly difficult positions, where high elevation and perfect stability are requested [1].

The design innovation, introduced by this relatively recent equipment, consists in an union between the flexibility of a van with a mobile ladder and the functionality of the aerial platform [2].

The sliding boom of the telescope permits the platform to reach the highest working positions offering, at the same time, a safe place for workers, as fire fighters, with good handling and operating characteristics [3].

These mechanical devices represent a valid solution in providing temporary access for people or equipment to inaccessible areas, usually at height. They are generally used for provisional, flexible access purposes, such as maintenance and construction works or by firefighters for emergency access, which distinguish them from permanent access equipment such as elevators. Adding, they are designed to lift limited weights, distinguishing them from most types of cranes.

In particular, the family of telescopic platforms under investigation is capable of rising up to 20 meters, offering extremely compact overall dimensions.

Equipped with proportional electro-hydraulic controls mounted both in the basket and at ground level, they feature $360^{\circ}$ rotation turret.

Common applications of these platforms include civil and building constructions, electrical systems, lighting, industrial plants, ship yard, transport, cleaning services, maintenance (Fig. 1) and many others.
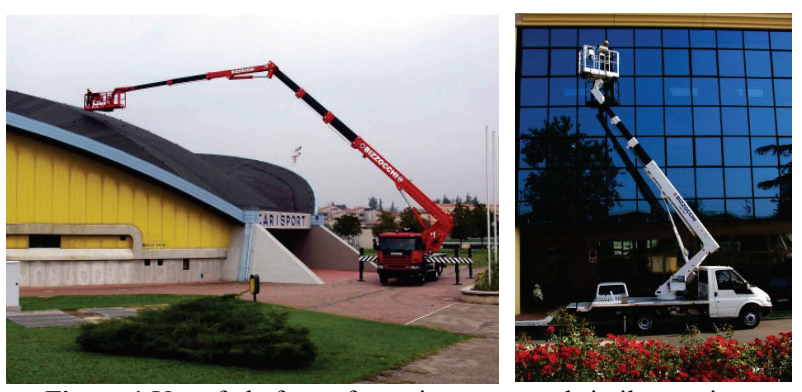

Figure 1 Use of platforms for maintenance and similar services

Despite the general relevance, few investigations have been actually focused on these useful devices.

This absence of information is relevant, above all, in the field of structural stability that, on the contrary, probably represents the most critical aspect to be awarded before designing these slim and light structures.

The phenomenon of the instability with respect to the compressive loads (or buckling) is a growing problem since the relatively recent possibility to select very high strength materials in construction. As a consequence, designers are allowed to reduce weight using very thin sections, most subject to risks of instability [4].

The elastic instability was treated for the first time in a complete way in 1744 by Euler, who defined it as a concept of critical load as the load limit beyond which even if there is a minimum movement of the beam, or media, or of the load, the structure collapses $[5,6]$. 
Instead, as long as it remains below the critical value, each lateral displacement imprinted to the beam produces an elastic internal moment more than sufficient to restore the initial straightness.

Experiments showed that for beams relatively long and slender, the so-called warping or buckling occurs, that is a phenomenon of collapse, even when the stress is well below the strength limit of the material [7].

The tendency in a load-displacement diagram for a streamlined structure is such that up to a particular value the structure is deformed in a conventional manner (elastic/plastic), but as soon as it reaches the critical load it has a bifurcation of the curve, which leads to theoretically infinite displacements and to rapid collapse of the structure. With increasing the length of the component the role of the geometry and stiffness becomes crucial in guaranteeing the resistance. The box beams (as booms) have a good resistance to this failure mode, but when local buckling occurs on thin-walled structures it can be seen from the development of inflation and ripples [7].

In the analysis of telescopic booms, regarding a large gamma of general aspects as models, stress evaluation, deflection or buckling, it is a common practice to refer to investigations primarily developed on telescopic cantilever beams (as $[8 \div 11]$ ) or on cranes.

In [12], for instance, useful considerations on the effect of moving masses on the dynamic behaviour of a crane are reported. In [13], a method for evaluating the maximum extension of a bucket wheel boom in static and dynamic situation is suggested. In [14] a feature analysis in the case of ultra-light telescopic mechanisms for cranes is proposed.

Some of these researches are deeply in line to the present analysis. In [15] linear and nonlinear buckling and post buckling phenomena are investigated in the case of a bar, also considering the influence of imperfections. In [16], the optimization of thin structures by ANSYS is detailed. In [17] a way for reducing experimental costs in welded structures was investigated.

Moreover, between other general aspects to be taken in consideration, [18] provides a practical approach for improving the reliability and safety of similar systems by design changes. It is detailed, in particular, how experiments and simulations merge in a Total Quality strategy.

Recent studies are also focused on telescopic booms.

In particular, in the complementary [19] and [20] a complete modelling of telescopic boom in, respectively, plane and $3 \mathrm{D}$ cases is proposed. In [21] an interesting overview of potentialities and limits in the application of FEM methods to a telescopic boom mounted on a mobile platform is presented. This numerical study can be also related to the methodological approach [22] where a procedure for evaluating displacements in the case of extra-long telescopic booms is proposed, taking in account the effects of own weight and of very large deformations.

\section{Material and methods}

This study started from considering a specific telescopic platform, readily available on the market, and aimed at providing technical considerations of resistance and stability for further improvements in term of design.

At the moment, this mechanical device permits:

- $\quad$ working height: $17 \mathrm{~m}$

- platform height: $15 \mathrm{~m}$

- load capacity: $200 \mathrm{~kg}$ (in every position)

- $\quad$ working outreach: $9 \mathrm{~m}$.

This aerial system can be installed on relatively light vehicles as $3500 \mathrm{Kg} \mathrm{GVW,} 3400 \mathrm{~mm}$ WB vehicles.

In particular, this research aimed at joining both theoretical and FEM considerations with the aim at a better comprehension of the structural resistance and instability of the structure respecting the maximum loads estimated as possible during the working life.

A specific attention was focused on the sliding pads, special elements used for reducing the criticality emerging by a direct connection between the metal sheets. In detail, the study was developed by the phases of:

1) Design with the conceptual design of a case-study, specifically selected for the interest and feasibility. This phase passed by the definition of geometry, loading conditions and constraints.

2) Modelling with the aim at developing all the constructive solutions able to perform the test. This phase passed by the 3D CAD design of prototype and equipment requested for testing.

3) Simplification in order to permit the deployment of theoretical solutions, together with the exact estimation of stresses and deformations under the different load conditions. This phase passed by the definition of limits of applicability for these simplifications with respect to the real case.

4) Numerical Analysis in order to investigate by Finite Elements the presence of unexpected phenomena in terms of structural resistance and instability. This phase passed by the evaluation of stresses and strains in searching the conditions of usability of the system.

\section{Preliminary considerations 3.1 Case-study}

The system under investigation is shown in Fig. 2. It consisted of a reconstruction of the complex mechanism used for joining the different parts of the telescopic boom and consisting in two sliding pads. This connection was considered as representative of the most critical function of a real telescopic boom during use.

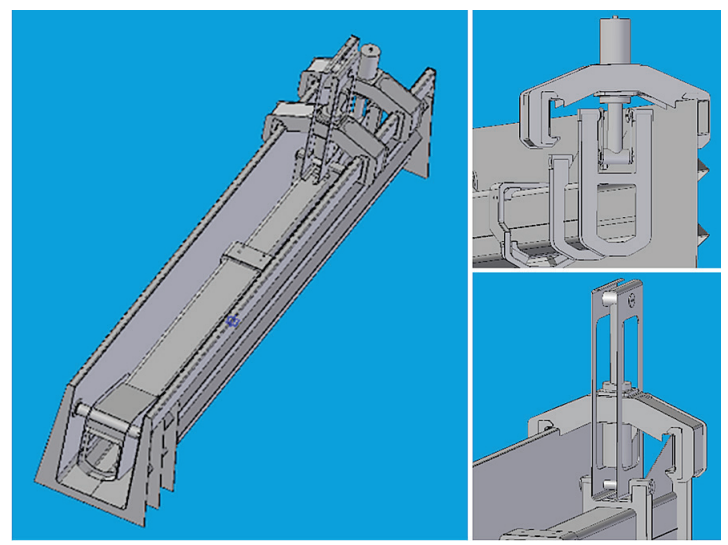

Figure 2 Telescopic boom and equipment for testing 


\subsection{Theoretical model}

The theoretical evaluation of forces and moments on the system was carried out by a simplified model (Fig. 3) in consideration of a real way of use of the telescopic boom (in terms of loads and constrains) and limiting the investigation on the most stressed zones. In particular, the effects of unexpected unbalanced loads (shear phenomena) and of overloads were investigated.

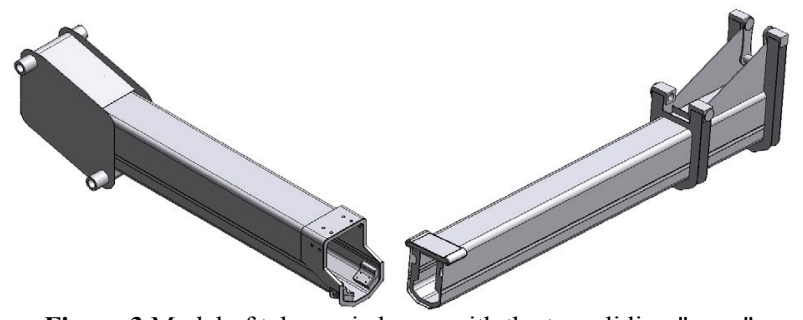

Figure 3 Model of telescopic boom with the two sliding "arms"

The simplest model, able to be described with good level of accuracy of the system, is a beam fixed in one end, by means of a double hinge and free in the other end (Fig. 4).

This simplification appears from the consideration to be in presence of a straight prismatic geometry, limited by two flat perpendicular bases that generate side surfaces very close to the points of application of loads.

In addition, all mass forces can be considered as negligible (with respect to the intense external loads), while the different parts are free from constraints for the most portion of their length (Lamé's Problem).

Furthermore, in a solid, made by elastic material (such as steel), the replacement of a given system of applied forces with another statically equivalent (having the same strength and the same resultant torque) as in the different mode of application and the law of distribution, has no influences in the sensitive points of the beam that are located at a certain distance from the point of application (De Saint Venant's Principle) [23].

In practice this system can be analysed in the same way as a slender beam, a solid having a size prevalent in respect to the others, undergoing small displacements and with loads and constraints applied to the ends (or nearly, as in the present case).

It should be immediately noted that, accepting this simplification all the local effects, caused by the particular mode of application of loads and constraints, as well as the rapid changes in the profile of the beam are lost. However, at the same time, calculations realized by this simplification, rapid and mostly correct, allow to properly identify the most critical areas to the varying conditions of loads.

A further step of simplification, made possible by the limited thickness of the metal sheets $(5 \mathrm{~mm})$, leads to the use of the De Saint Venant's theory for the beam with thin-wall, with hallow sections of rectangular shape and thickness equal to that of the $\mathrm{C}$ beams that form the different trunks of the boom. The geometries are like that, in fact, to recognize three different sections $(\mathrm{AB}, \mathrm{BC}$ and $\mathrm{CD})$ of the beam, with the central one (BC) with a reinforcement function in the connection (Fig. 4).
Given this variability in sections, also the moment of inertia is different and calculations shall be repeated for each section.

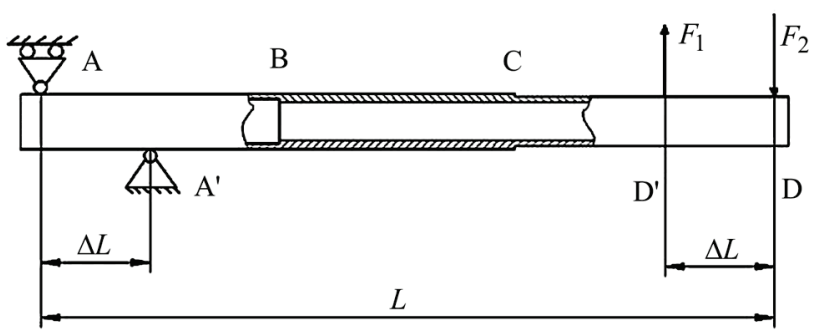

Figure 4 Schematic loads and constraints

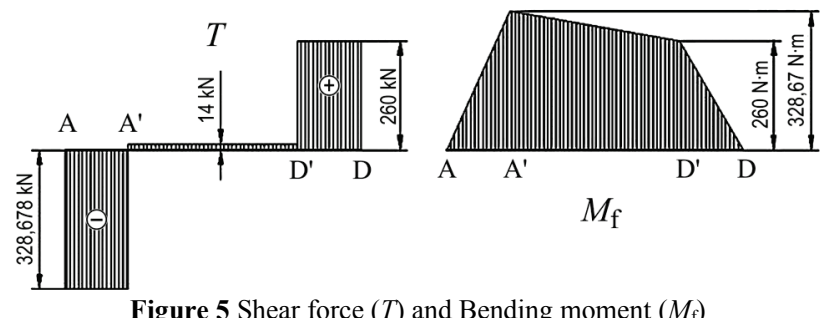

Figure 5 Shear force $(T)$ and Bending moment $\left(M_{\mathrm{f}}\right)$

The theoretical study, by the De Saint Venant's theory, for the thin beam, passed by the calculation of:

1) Moment of inertia (neutral axis) on three sections

2) Reaction forces

3) Shear and bending moment diagrams

4) Normal stress

5) Shear stresses (by Jourawski's model, suitable for thin closed sections)

6) Equivalent stresses (by criterion of Von Mises).

Actually, this study was not focused on reaction forces aiming to investigate the overlapping and contacts, away from where loads and constrains were applied. Coupled with a negligible shear stress in the central area, it let to ignore the contribution of shear (Fig. 5).

In practice, by this model, stresses on the telescopic boom were mainly limited to the bending moments.

The bending moment presented a linear increase (related to the variability of the sections) with a nearly constant value and maximum in the central zone (Fig. 5). It is therefore essential to consider the geometry of beams to find the most stressed sections (Tab. 1): in the case of nominal values of strength, expected from forces of $F_{1}=$ $246 \mathrm{kN}, F_{2}=260 \mathrm{kN}$, it can be evaluated as $223 \mathrm{MPa}$, far away from the steel yield strength $(\sim 1000 \mathrm{MPa})$.

Table 1 Theoretical stress-strain analysis

\begin{tabular}{|l|c|c|c|c|c|c|c|c|c|c|}
\hline & $\mathrm{A}$ & $\mathrm{A}^{\prime}-$ & $\mathrm{A}^{\prime}+$ & $\mathrm{B}$ & $\mathrm{B}+$ & $\mathrm{C}-$ & $\mathrm{C}+$ & $\mathrm{D}^{\prime}-$ & $\mathrm{D}^{\prime}+$ & $\mathrm{D}$ \\
\hline Force, $\mathrm{kN}$ & -328 & 342 & 342 & 0 & 0 & 0 & 0 & 0 & 246 & 260 \\
\hline Shear, $\mathrm{kN}$ & -328 & -328 & 14 & 14 & 14 & 14 & 14 & 14 & 260 & 260 \\
\hline Moment, $\mathrm{kN} \cdot \mathrm{m}$ & 0 & -328 & -328 & -308 & -308 & -282 & -282 & 260 & 260 & 0 \\
\hline$\sigma, \mathrm{MPa}$ & 0 & 132 & 132 & 124 & 12 & 11 & 223 & 206 & 206 & 0 \\
\hline$\tau, \mathrm{MPa}$ & 33 & 33 & 1 & 1 & 0 & 0 & 2 & 2 & 39 & 39 \\
\hline$\sigma_{\text {eq }}, \mathrm{MPa}$ & 67 & 148 & 132 & 124 & 12 & 11 & 223 & 206 & 220 & 78 \\
\hline
\end{tabular}

From this analysis it follows that, despite the limits related to the use of simplified models, the system (the telescopic boom) is already designed to survive too much higher loads. With the aim of searching the safety limit of this structure, external loads were progressively increased in simulation keeping stable the original ratio between the 
two forces $\left(F_{1} / F_{2}=94,61 \%\right)$. It means, in practice, that the contribution of shear was substantially preserved when the bending moment was increased. In such conditions the yield stress approached the yield limit of material only with loads 4 times higher (Fig. 6).

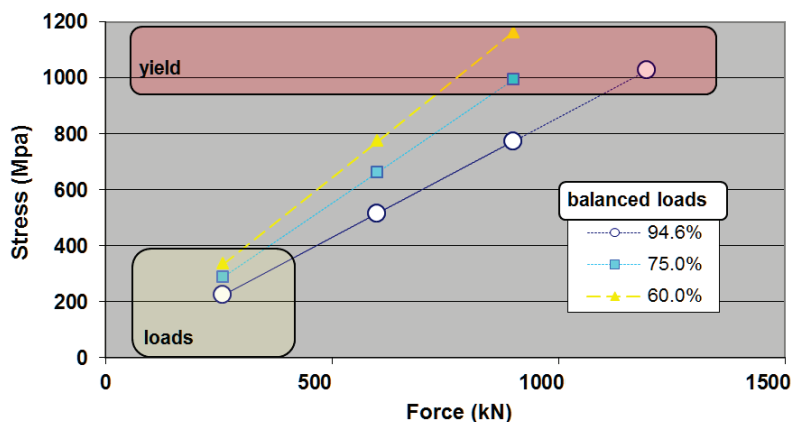

Figure 6: Effects in term of stresses of increasing in loads intensity and in loads unbalancement

\section{Numerical simulation \\ 4.1 Discrete model}

Starting from these quite heavy simplifications, more complex models were progressively adopted, with the aim at simulating geometries and conditions similar to the real ones. ANSYS WB 14 and CATIA 5 were used.

In the discretization, tetrahedral Finite Elements (FE) with 10 nodes were preferred, able to guarantee an adequate accuracy even with a limited number of nodes (Fig. 7). These FEs made the numerical solution quick and precise [24, 25].

Referring to the dimension of FEs, it was customized with smaller dimensions in areas of particular interest in order to optimize the computing capacity and the accuracy of analysis. More than 140000 elements and 280000 nodes were necessary for discretization.

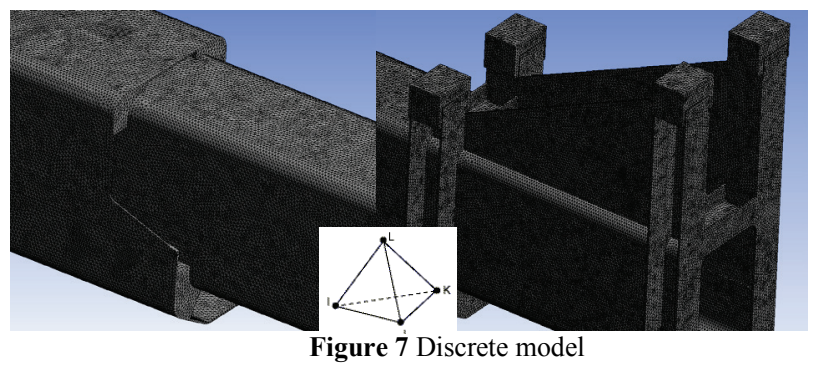

With the aim at verifying the optimal dimension of FE, some simulations were repeated with different meshes and results compared taking also in consideration the time machine. In particular, as ideal mesh, it was validate a grid of nodes very dense in the area of junction (with FE not larger than $20 \mathrm{~mm}$ ), quite sparse in the remaining part of the boom $(80 \mathrm{~mm})$, and widely spaced in the huge support structure $(120 \mathrm{~mm})$.

\subsection{Simplified mode}

In the way of deploying an initial, approximated, but very fast numerical simulation, a first simplified model (labelled as "single body") was realized with the extreme assumption to consider all parts of the assembly, actually more than one hundred, as "welded together" in one single piece of the same material, steel.

Even the six sliding pads were initially considered as made of steel, accepting all relative errors in modelling.

These simplifications avoided, at least at the moment, to enter into the complex mechanisms of contact between surfaces (involving 300 contact situations), but to focus the attention on several preliminary validations, as $3 \mathrm{D}$ CAD model and overall strength of the structure.

In particular, welds, holes and many other small details provided in the original design disappeared thanks to offering regularity in geometry and easy simulations.

In spite of the simplification, results provided by FE are valid when taken at a certain distance from the discontinuities and critical areas (Fig. 8). In particular, the single body model allowed verifying that:

1) both stresses and strains were in line with the theoretical evaluation and, consequently, the system was distant from the conditions of yielding

2) sheets did not show effects of instability

3) support structures could resist to the expected loads

4) connecting parts (as pins, rods, etc.) were correctly dimensioned.

The use of this homogeneous model, characterized by a relatively low computing time (not more than $6 / 8$ hours), allowed to realize a large variety of simulations, comparing the numerical results.

In particular it permitted to investigate:

- $\quad$ uniformity, repeatability and stability of results

- degree of optimal smaller elements

- local meshing criticalities

- $\quad$ structure response respect to changes in loads

- disruptive effect of shear related to unbalanced loads.
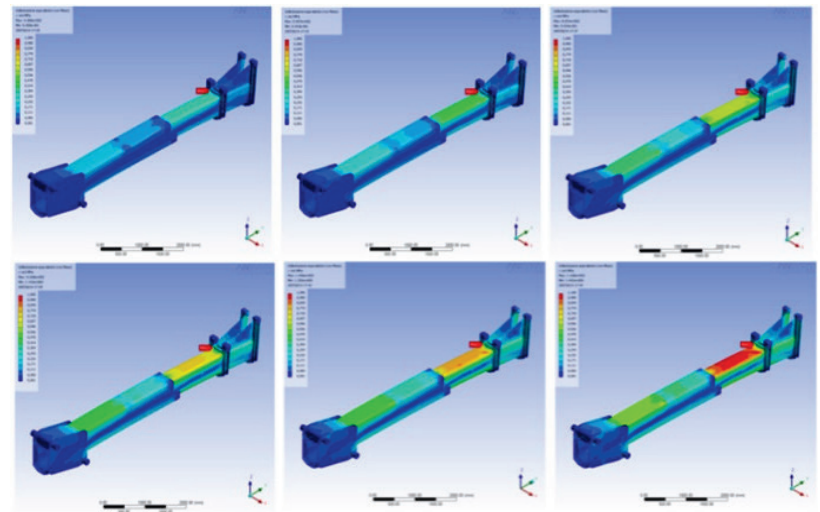

Figure 8 Structure response increasing the loads

\subsection{Complex model}

These results, valid for consideration on the overall structure, were useless to understand what really happens in the region of contact inside the telescopic boom.

The simplification of considering the sliding pads as equivalent to a steel part, welded on the other steel parts, let them reacting in all directions.

On the contrary, in the real case, these pads only reacted to compression, surely not in traction or in longitudinal direction (with the exception of a negligible force associated to the tangential friction during a marginal sliding). 
Furthermore, the plastic used for the realisation of sliding pads, named as Ertalon [26] presents a stiffness much lower than AISI 4130 (water quenched at $855^{\circ} \mathrm{C}$, $480{ }^{\circ} \mathrm{C}$ temper [27]). This difference, if ignored, drives wrong considerations about the level of reinforcement offered by the telescopic boom in its central segment. To overcome these limitations, a new model was considered, able to investigate what happened in contacts. It consisted in 2 tubular parts in steel and 6 sliding pads in Ertalon.

Geometry was simplified even in this case, but only in zones of marginal interest (e.g. threading, welding, etc.). Moreover, the whole support frame and the mechanism for the transmission of forces and constraints, deeply investigated in the previous model, were eliminated now, in consideration of the negligible effects that their presence produces on the contact area.

In practice, in this second study, the whole attention was focused on investigating how contact and forces were transmitted between the tubular trunks, passing by the sliding pads.

Considering that both theoretical or experimental information was missing on what could happen in the elastoplastic area, including possible viscoelastic sliding, it was decided to perform several simulations varying the modelling assumptions in the contact zone (Fig. 9).
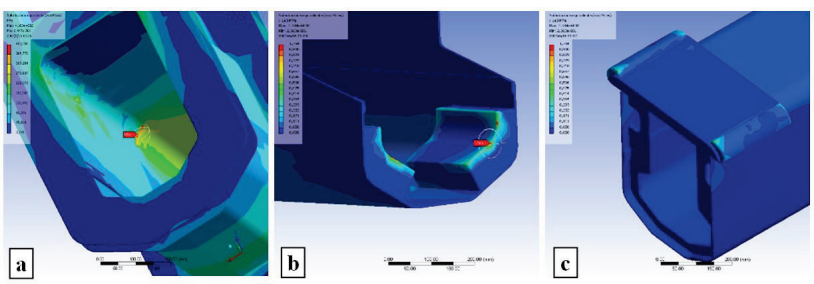

Figure 9 Details of the contact zone: a) the area of maximum stress on the boom; b) lower sliding pads and c) above sliding pads

In particular, the contact mode characterizing the 3 pairs of sliding pads was set on "frictionless" (equivalent to a constraint of two-dimensional pinned boundary) or on "bounded" in the case of clamped boundary.

Adding, the material properties of Ertalon, unknown with precision, were changed, varying from very soft to very stiff limits.

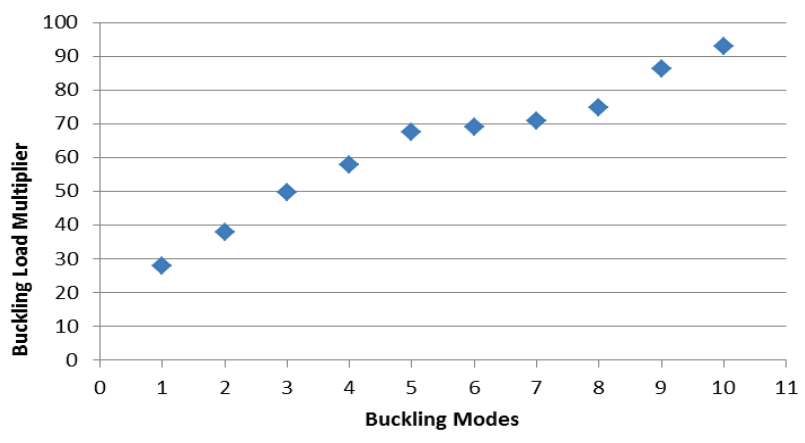

Figure 10 Buckling Load Multipliers

\subsection{Instability and compression}

The simulation also allowed analysing the behaviour of system with respect to the effect of instability by finding buckling modes, namely the geometrical configurations which could assume the system in the case of instability, and the load multipliers for which this instability occurs (Fig. 10), a kind of safety factor on the applied forces.
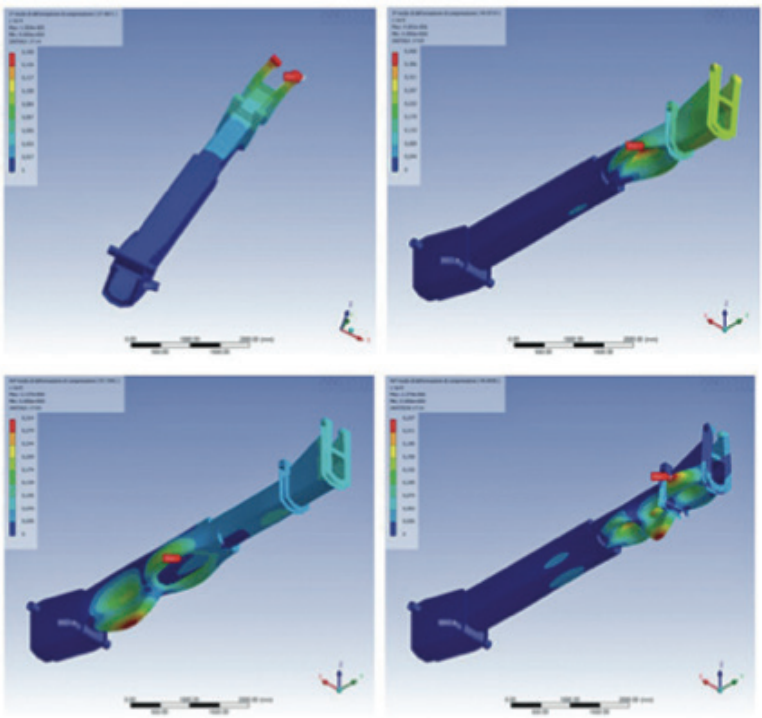

Figure 11 Examples of buckling modes

\section{Discussion}

The numerical simulation provided a framework of results, able to limit the response of the telescopic boom.

In general, by FE simulations it was possible to highlight that the maximum stresses were quite close in respect to those estimated by theoretical evaluations. The difference raised up to $15 \div 20 \%$ in specific zones characterized by high discontinuity in geometries and, then, local stress concentration. Anyway, stress levels were always far from the yield limits of the structure.

Moreover, the very small thickness of the metal sheets guaranteed a significant uniformity in the stress along the depth, in a biaxial stress state.

Entering in details, FE investigations showed an initial non-linear behaviour of the system with large displacements for small values of the load to which a fairly linear part followed. The initial trend is definitely linked to the recovery of pads' movements, the twist caused by the asymmetry of the system and the viscoelastic behaviour of sliding pads in Ertalon.

By correcting the simulation model to take account of an existing asymmetry in the area of contact, the FE analysis provided highly accurate results. Even in this case, the boom was in the elastic range $(<1000 \mathrm{MPa})$ and could operate without particular risks: in nominal load conditions a peak of stress of $728 \mathrm{MPa}$ was estimated in the contact zone, between the lower sliding pads and the internal extension. Increasing the load, the soft sliding pads in Ertalon reach early (as expected) the yield stress and deform bringing in that way extension in the contact zone and redistribution of the tensions in the steel lowering localized peaks: in the upper surface of the internal sliding pads (the most critical for the strength of the structure) does not even reach $300 \mathrm{MPa}$. It is believed that, by loading the sliding pads more of what has been done, the plasticity of the element was going to affect the joints with the bottom surface and side walls extending the section concerned with the coverage and reducing stresses. 
From the comparative study of different hypotheses it was curious to see how the position of the peaks of the stress in the steel was slightly modified varying the stiffness of the sliding pads: softer plastics slightly reduce the peaks in the steel and away from the edge of the sliding pads. In a corresponding manner, with the use of less rigid materials, the sliding pads are shrinking tension peaks reaching approximately $230 \mathrm{MPa}$ (in compression) while increasing the total deformation of the structure.

Referring to the buckling, FE simulations demonstrated that, at least on the simplified model with a single body, the buckling occurs at loads much higher than sustainable by the material. In the assembled models, load multipliers vary significantly according to contact hypothesis accepted; assuming the worst case the load multiplier takes values that are slightly above the breaking point of the structure. Consequently, it is considered that, in practice, phenomena of instability compression (as in Fig. 11) did not arise before the yield point of the boom.

By numerical simulations, providing a pure bending moment, it was derived that the boom should collapse under a pure moment of more than $1000 \mathrm{kN} \cdot \mathrm{m}$ (or a combination of moment of $923 \mathrm{kN} \cdot \mathrm{m}$ and shear $52,5 \mathrm{kN}$ ). These values correspond to external loads 4 times higher than the design limits for the system and cannot be reasonably achieved during normal functionality, even in conditions of sudden stop or overload.

\section{Conclusion}

In this study theoretical and FE estimations permitted to validate strength and stability of a telescopic boom.

In particular, FE showed that this telescopic boom is free from buckling or other unexpected phenomena that could compromise the safety of users. Combining theory and more than 50 numerical simulations (different in model complexity, loads, constrains, contact conditions) provided evidences that this mechanical system was correctly designed and sized to perform its work in circumstance with loads 3 times higher with respect to the nominal conditions.

Anyway, a special attention has to be focused on limiting unbalances of loads and the influence of shear.

FE were also used for investigating the sliding pads, extremely critical parts of the system. It was found that the structure with its length, weight and position of sliders would not provoke buckling of the entire structure.

By this sequel of activity, it was possible to create a simple methodology for a fast verification of design assumptions. The basic idea was to define some safety coefficients, able to take into account in a proper way and even in critical localized areas the differences between theoretical simplified models and real ones.

Finally, from this paper it is evident how numerical simulations could be used as a reliable method in the design and verification of complex structures similar to the one just examined, reducing the necessity of complex experimental tests. At the same time, experiments are irreplaceable for validating numerical models and, thus, represent the next step of investigation.

\section{References}

[1] EN 280:2000 standard. Mobile elevating work platforms. Design calculations. Stability criteria. Construction. Safety, Examinations and tests.

[2] Joyce, N. Design of a mobile elevating work platform, M.Phil Thesis, Brunel University 1995.

[3] Włodzimierz, S. Mobile platforms. Construction and exploitation, Krosno (2003) KaBe.

[4] Tvergaad, T. Studies of Elastic-Plastic Instability. // Journal of Applied Mechanics. 66, (1999), pp. 3-9. DOl: 10.1115/1.2789166

[5] Timoshenko, S. P.; Gere, J. M. Theory of elastic stability. Courier Corporation, 2009.

[6] Bažant, Z. P.; Cedolin, L. Stability of structures: elastic, inelastic, fracture and damage theories. World Scientific, 2010. DOI: $10.1142 / 7828$

[7] Arbocz, J.; Weller, T. Buckling Experiments, Basic Concepts, Columns, Beams and Plates. Vol. 1. John Wiley \& Sons, 1998.

[8] Abraham, J.; Sivaloganathan, S.; Rees, D.W.A. The Telescopic Cantilever Beam: Part 1 - Deflection Analysis, Engineering Integrity, February 2011.

[9] Abraham, J.; Sivaloganathan, S.; Rees, D. W. A. The Telescopic Cantilever Beam: Part 2 - Stress Analysis, Engineering Integrity, September 2011.

[10] Jeevan, G. A. A Deflection, Buckling and Stress Investigation into the Telescopic Cantilever Beam, doctoral thesis at School of Engineering and Design, Brunel University, January 2012.

[11] Gaafar, M. L. A. Large deflection analysis of a thin-walled channel section cantilever beam. // International Journal of Mechanical Science. 22, 12(1980), pp. 755-766. DOI: 10.1016/0020-7403(80)90060-0

[12] Gasix, V.; Zrnic, N.; Rakin, M. Consideration of a moving mass effect on dynamic behaviour of a JIB crane structure. // Tehnicki Vjesnik. 19, 1(2012), pp. 115-121

[13] Petrovic, B.; Petrovic, A.; Ignjatovic, D.; Grozdanovic, I.; Kozak, D.; Katinic, M. Assessment of the maximum possible extension of bucket wheel SchRs740 boom based on static and dynamic calculation. // Tehnicki Vjesnik. 23, 4(2016), pp. 1233-1238.

[14] Ergic, T.; Ivandic, Z. Ultra-light telescopic crane/platform mechanisms feature analysis. // Tehnicki Vjesnik. 16, 4(2009), pp. 87-91

[15] Novoselac, S.; Ergic, T.; Balicevic, P. Linear and nonlinear buckling and post buckling analysis of a bar with the influence of imperfections. // Tehnicki Vjesnik. 19, 3(2012), pp. 695-701.

[16] Beno, P., Kozak, D., Konjatic, P. Optimization of thinwalled constructions in CAE system ANSYS. // Tehnicki Vjesnik. 21, 5(2014), pp. 1051-1055.

[17] Rakin, M.; Arsic, M.; Bosnjak, S.; Gnjatovic, N.; Medo, B. Integrity assessment of bucket wheel excavator welded structures by using the single selection method. // Tehnicki Vjesnik. 20, 5(2013), pp. 811-816.

[18] Fragassa, C.; Pavlovic, A.; Massimo, S. Using a Total Quality Strategy in a new Practical Approach for Improving the Product Reliability in Automotive Industry. // International Journal for Quality Research. 8, 3(2014), pp 297-310.

[19] Heikki, M.; Jari, M. Modelling telescopic boom- The plane case: part I. // Computers \& Structure. 81, (2003) pp. 1597 1609. DOI: $10.1016 / S 0045-7949(03) 00185-8$

[20] Heikki, M.; Jari, M. Modelling telescopic boom- The 3D case: part II. // Computers \& Structure. 84, (2006) pp. 2001-2015. DOI: 10.1016/j.compstruc.2006.08.010

[21] Derlukiewicz, D.; Przybyłek, G. Chosen aspects of FEM strength analysis of telescopic JIB mounted on mobile 
platform. // Automation in construction. 17, 3(2008), pp. 278-283. DOI: 10.1016/j.autcon.2007.05.009

[22] Gening, X.; Guangheng, G. Displacement Calculation Method of Superlong Telescopic jib Structure Considering the Effect of Self Weight and Large Deformation. // Research and Applications in Mechanical Engineering. 2, 4 (2013).

[23] Pian, T. H.; Tong, P. Basis of finite element methods for solid continua. // International Journal for Numerical Methods in Engineering. 1(1969), pp. 3-28. DOI: 10.1002/nme.1620010103

[24] Bathe, K. J. Finite element method. John Wiley \& Sons, Inc. 2008. DOI: 10.1002/9780470050118.ecse159

[25] Wallin, M. A Finite Element tool for linear buckling analysis, Master thesis at Linköping University LIU-IEITEK-A-14/01981-SE Saab report LN-017310.

[26] MatWeb Material Portal Data. Ertalon. http://www.matweb.com/search/GetMatlsByTradename.asp $\mathrm{x} ? \mathrm{tn}=$ Ertalon $\% \mathrm{C} 2 \% \mathrm{AE}$

[27] MatWeb Material Portal Data. AISI 4130 Steel. http://www.matweb.com/search/datasheet.aspx?MatGUID= $722 \mathrm{e} 053100354 \mathrm{c} 02 \mathrm{a} 6 \mathrm{~d} 450 \mathrm{~d} 5 \mathrm{~d} 7646 \mathrm{~d} 82 \& \mathrm{ckck}=1$

\section{Authors' addresses}

Ana Pavlovic, Adjunct Professor

Corresponding author

Alma Mater Studiorum University of Bologna,

Viale Risorgimento 2, 40136 Bologna, Italy

E-mail: ana.pavlovic@unibo.it

Cristiano Fragassa, Assistant Professor

Alma Mater Studiorum University of Bologna,

Viale Risorgimento 2, 40136 Bologna, Italy

E-mail: cristiano.fragassa@unibo.it

Giangiacomo Minak, Associate Professor

Alma Mater Studiorum University of Bologna,

Viale Risorgimento 2, 40136 Bologna, Italy

E-mail: giangiacomo.minak@unibo.it 